\title{
O ESTATUTO DAS NOVELAS DE CAVALARIA LUSITANAS DO SÉCULO XVI EM HISTORIOGRAFIAS DA LITERATURA PORTUGUESA
}

\author{
EL ESTATUTO DE LOS LIBROS DE CABALLERÍAS LUSITANOS DEL SIGLO XVI EN \\ HISTORIOGRAFÍAS DE LA LITERATURA PORTUGUESA
}

RESUMO: Em Portugal, a novela de cavalaria perdurou para além da Idade Média, de modo que, em meados do século XVIII, ainda se tem notícia de escritos nesse subgênero literário. No entanto, apesar disto, poucos estudos teóricos em Português trataram, até hoje, sobre esse tema. Sendo assim, tendo em vista a sua longa permanência no país, buscou-se entender, neste estudo, a partir de uma análise comparativa entre quatro historiografias da literatura portuguesa - Remédios (1930); Figueiredo (1960); Saraiva e Lopes (1956) e Moisés (2013) - que obtiveram circulação em universidades brasileiras e lusas, qual era o espaço reservado pelos historiadores da literatura para a novela de cavalaria no século XVI frente às demais manifestações literárias do período. De modo geral, como resultado da investigação empreendida neste trabalho, foi possível observar que, na maioria das vezes, Camões e sua epopeia ocupam, nos capítulos dedicados ao Renascimento lusíada, uma centralidade absoluta. Tal fato acaba deixando os escritos de novelistas como João de Barros, Jorge Ferreira de Vasconcelos, Francisco de Moraes e Diogo Fernandes à margem. Por fim, pudemos concluir que as historiografias nacionais da literatura atendem às necessidades nacionalistas herdadas por elas do Romantismo e, sendo assim, não raramente historiadores literários comparam ou tentam interligar as novelas de cavalaria quinhentistas analisadas por eles ao épico camoniano, rebaixando-as, muitas vezes, à condição de inferiores e anacrônicas, uma vez que, a partir do século XIX, Os Lusíadas passaram a encerrar em si a identidade cultural do povo luso.

Palavras-chave: Historiografia literária; novelas de cavalaria do século XVI; literatura portuguesa.

RESUMEN: En Portugal, la novela de caballería duró más allá de la Edad Media, de modo que, a mediados del siglo XVIII, todavía hay noticias de escritos en este subgénero literario. Sin embargo, a pesar de esto, pocos estudios teóricos en portugués han tratado este tema hasta el día de hoy. Así, teniendo en vista su larga estadía en el país, buscamos comprender, en este estudio, a partir de un análisis comparativo entre cuatro historiografías de la literatura portuguesa - de Remédios (1930); Figueiredo (1960); Saraiva y Lopes (1956) y Moisés (2013) - que obtuvieron circulación en universidades brasileñas y portuguesas, cuál fue el espacio reservado por los historiadores de la literatura para la novela de caballería en el siglo XVI en comparación con otras manifestaciones literarias de la época. En general, como resultado de la investigación realizada en este trabajo, se observó que, en su mayor parte, Camões y su épica ocupan, en los capítulos dedicados al Renacimiento lusíada, una centralidad absoluta. Este hecho termina dejando al margen los escritos de novelistas como João de Barros, Jorge Ferreira de Vasconcelos, Francisco de Moraes y Diogo Fernandes. Finalmente, podríamos concluir que las historiografías nacionales de literatura satisfacen las necesidades nacionalistas heredadas por ellos del Romanticismo y, por lo tanto, no es raro que los historiadores literarios comparen o intenten vincular las novelas de caballería del siglo XVI analizadas por ellos en sus trabajos a la epopeya de Camonia, , a menudo rebajándolas al estatus de inferior y anacrónico, una vez que, desde el siglo XIX, Los Lusíadas

\footnotetext{
${ }^{1}$ Doutoranda em Teoria da Literatura pela Universidade Federal de Pernambuco-UFPE.
} 
comenzaron a contener en sí mismos la identidad cultural de lo pueblo portugués.

Palabras-clave: Historiografía literaria; novelas de caballería del siglo XVI; literatura portuguesa.

\section{Apresentação}

De origem oral, as lendas arturianas, herdeiras de tradições celtas da Grã-Bretanha e da Armórica, foram registradas em livro pela primeira vez no nobiliário Historia Regum Britanniae, de Geoffroy de Monmouth, redigido em latim, provavelmente, entre os anos 1135 e 1138 . Afora o clérigo galês, poetas como Robert Wace e Layamon difundiram para leitores normandos e ingleses, respectivamente, essa mesma tradição. No entanto, somente anos mais tarde, com Chrétien de Troyes, as narrativas em torno do Rei Artur e de sua Távola Redonda consolidaram-se de vez no terreno da literatura Ocidental, atrelando-se, em maior parte, a uma forma literária específica: a novela de cavalaria². Além desse último, Robert de Boron, outro autor francês, exerceu um papel fundamental no desenvolvimento desse subgênero: a atribuição de uma linearidade histórica aos seus livros que, posteriormente, inspirou a organização dos textos literários de outros escritores que se inscrevem nessa tradição.

Em Portugal, versões francesas de novelas de cavalaria arturianas ${ }^{3}$ foram introduzidas no reinado de D. Afonso III no século XIII. Dentre elas, a tradução para português d'A Demanda do Santo Graal possuía grande popularidade. No entanto, segundo Massaud Moisés (1957), até o fim do século XV não houve em terras lusitanas publicações autorais nesse subgênero literário. Sendo assim, somente a partir do Quinhentismo, então, poder-se-ia tratar de novelas de cavalaria lusas. Desse momento em diante, inclusive em meados do século XVIII - no decorrer de três séculos, portanto -, diversos autores lusos escreveram esse tipo de narrativa. Por conseguinte, esse mesmo fenômeno também se estende para a Espanha. Para se ter uma noção do volume de publicações dessa categoria narrativa, em 1857, o espanhol Pascual de Gayangos publicou um extenso catálogo onde discriminou todas as publicações de novelas de cavalaria, dos Ciclos Clássico, Greco-Asiático, Carolíngio, Arturiano, entre outros; produzidos dos anos 1500 a 1800 na Península Ibérica; realizou comentários sobre livros selecionados por ele e copilou trechos desses. Algumas das obras lusitanas do século XVI mencionadas foram: Crônica do Imperador Clarimundo, donde os reis de Portugal descendem, de João de Barros (1522); Palmeirim de Inglaterra, de Francisco de Moraes (Livro I, Toledo; 1547, e Livro II, Toledo, 1548); Triunfos de Sagramor (ou Memorial de Proezas da Segunda Távola Redonda, reescrita datada do ano de 1567), de Jorge Ferreira de Vasconcelos (1554); Duardos de Bretanha, de Diogo Fernandes (1587). Sobre o

\footnotetext{
${ }^{2}$ Inicialmente, as novelas de cavalaria foram escritas em versos. No caso das cinco que se tem certeza que foram elaboradas por Chrétien de Troyes, o metro utilizado era o octassílabo. A forma em prosa desse subgênero literário, a qual se popularizou ao longo dos séculos, é um fenômeno posterior e decorre de uma transformação formal da própria novela, que se deu por meio da prosificação, por volta da segunda metade do século XIII, de textos épicos poéticos ligados, por exemplo, à Matéria da Bretanha; bem como as histórias sobre Carlos Magno e seus pares.

${ }^{3}$ De acordo com Ivo Castro (2001), o Códice de Viena da versão lusitana d'A Demanda do Santo Graal - o qual data do século XV - apresenta maiores similaridades com o texto original francês que a tradução feita em castelhano. Por essa razão, supõe-se que essa obra, e certamente outras do mesmo gênero, adentraram Portugal em língua francesa e não a partir de uma tradução. Somente depois, não se sabe ao certo a data, o texto de La Queste del Saint Graal foi transposto para o Galego-português.
} 
estatuto desses quatro livros diante do cânone lusíada do século XVI, determinado em algumas historiografias literárias, pretendo tratar neste breve ensaio.

O Ciclo Arturiano foi o primeiro a adentrar as fronteiras lusíadas. Após ele, os demais ciclos medievais e tantos outros que começaram a surgir a partir do século XV tiveram lugar, a exemplo do Ciclo dos Palmeirins e o dos Amadizes. No caso da prosa cavaleiresca portuguesa do século XVI, as obras de Francisco de Moraes e Diogo Fernandes seguem a tradição do primeiro, ao passo que Jorge Ferreira de Vasconcelos, em sua primeira e única novela de cavalaria $^{4}$, interliga-se ao legado deixado ao mesmo tempo pela Matéria da Bretanha e o Amadis de Gaula (século XVI). Já o Clarimundo, apresenta também pretensões de cunho historiográfico e não se encaixa exatamente em nenhum dos ciclos anteriores ${ }^{5}$.

Contudo, apesar da tradição épica legada pela novela de cavalaria medieval em Portugal desde o século XIII - a partir das primeiras obras cavaleirescas arturianas - até o XVIII momento em que se nota a publicação dos últimos textos efetivamente desse subgênero literário -, a importância desses, principalmente após o século XV é, muitas vezes, negligenciada nas Histórias da Literatura Portuguesa, trazendo para a margem uma tipologia narrativa que se fez cânone durante a Idade Média Ocidental. Diante do legado que uma obra como El ingenioso hidalgo Don Quijote de La Mancha, de Miguel de Cervantes, concedeu à modernidade em 1605, ao trazer à tona o romance moderno e assinalar a caducidade das narrativas de cavalaria, dar relevo, na posteridade, à longa permanência de publicações desse tipo de narrativa em Portugal seria, para diversos teóricos e críticos, admitir certo anacronismo no país diante das novas tendências estéticas e formas literárias que surgiram entre 1500 e 1800 . Ademais, quanto ao século XVI, o épico e as obras líricas ${ }^{6}$ camonianas estavam mais próximos das propostas estéticas herdadas do Renascimento italiano, não obstante Os Lusíadas apresentassem um mundo regido por uma ótica cristã e alguns traços poéticos maneiristas, os quais, inclusive, também perpassam a sua produção lírica. Afora isso, a epopeia construída por Camões revelavase bastante interessante para o projeto romântico de criação e consolidação de um cânone literário atrelado aos ideais de estabelecimento de uma identidade nacional. Esses ideais, inclusive, são os principais norteadores da organização, a partir do século XIX, das historiografias literárias de diversos países.

\section{História, história da literatura e historiografia literária: algumas considerações}

As origens da noção de História enquanto conceito, sistema e disciplina, assim como se concebe atualmente, é um fenômeno que, conforme Reinhart Koselleck (2016), remonta ao final do século XVIII. Antes disso, havia, na Antiguidade, uma "Historie", que encerrava em si narrativas diretamente ligadas à memória e que serviam para o registro e conhecimento de

\footnotetext{
${ }^{4}$ Jorge Ferreira de Vasconcelos era comediógrafo e escreveu obras do gênero durante boa parte de sua vida, ao passo que o Memorial de Proezas da Segunda Távola Redonda apresenta-se como um ponto fora da curva diante de sua obra consolidada quase totalmente no teatro.

${ }^{5}$ Sobre isso, veja o Catálogo Razonado, de Pascual de Gayangos (1857), na seção 3, a partir da página 72, ou LXXII, como está posto no livro.

${ }^{6}$ Nos poemas líricos de Camões, mesmo quando a forma revela-se medieval - em redondilha maior ou menor -, o conteúdo e as tópicas abordadas já diferem do que se encontra no interior da poesia trovadoresca.
} 
determinados fatos passados vivenciados de modo direto por um grupo de indivíduos que pudesse testemunhá-los. Nesse sentido, a ideia de "contemporaneidade do não contemporâneo" (KOSELLECK, 2016, p. 39) relacionada, de forma autoconsciente, à escrita historiográfica consolida-se, de fato, no século XIX.

Por muito tempo, a História esteve relacionada a eventos contemporâneos de um povo que merecia, de acordo com os indivíduos detentores do poder, obter registro para ser rememorado pela posteridade. Destarte, como se pode supor, ela servia principalmente a interesses políticos particulares e imediatos de um determinado grupo. Diante disso, a escrita de um determinado fato centrava-se nele mesmo e não pretendia sistematizá-lo diante de outros acontecimentos. Desse modo, a situação narrada - concebida, ainda, como uma verdade apreensível e recuperável por meio da escrita - encontrava-se em primeiro plano, ao passo que a análise minuciosa da conjuntura em que esse estava inserido não possuía sequer relevo. $\mathrm{Na}$ Idade Média, como afirma Christian Meier (2016, pp. 47-48):

Sem dúvida, o conceito de "História" existia, mas era utilizado sobretudo para a forma, para o invólucro, e apenas secundariamente para todo o conjunto de ações, de acontecimentos e de transcursos que ele continha. Do ponto de vista do conteúdo, ele visava muito mais à soma das Historie(n). Não se visava um movimento dinâmico, uma grande corrente, na qual se pudesse determinar um lugar, cuja unidade se pudesse assumir, cujo sentido se pudesse buscar.

No século XIX, a História firma-se como disciplina e, a partir desse momento, iniciou-se um processo de consolidação de métodos e pressupostos que a caracterizassem como tal e definissem para ela uma abordagem científica sistemática e objetiva. Assim, o testemunho ocular, sob a forma de um relato oral, sobre algum fato ocorrido perde sua centralidade, cedendo espaço ao documento escrito, que se tornou, então, a fonte histórica por excelência, por meio da qual se poderia ter acesso ao passado, que se configurou como o objeto prioritário da investigação histórica:

O projeto oitocentista de escrita da História consagrou os registros escritos como centrais para os procedimentos da disciplina, que se fundava a partir de duas preocupações centrais: definir a pesquisa do passado segundo os parâmetros de uma investigação científica sistemática e controlável e ainda legitimar, recorrendo ao próprio passado, as aspirações contemporâneas relativas à criação dos Estados nacionais. [...] A história política como biografia da Nação ou dos seus heróis fundadores tornou-se o gênero por excelência da História disciplinar praticada nos espaços acadêmicos. (GUIMARÃES, 2010, pp. 35-36)

A origem da História da Literatura, por sua vez, interliga-se ao surgimento de uma ciência histórica autônoma, que possui uma consciência reflexiva de si mesma e de seus objetos de estudo. Mais do que isso: ciente de seus aspectos e de seu papel perante a sociedade de seu tempo, a historiografia pode contribuir, por meio do resgate de seletos fragmentos do passado, para o projeto oitocentista de construção e consolidação de uma identidade nacional em cada país que dela fizesse uso. Destarte, o registro sistemático de um determinado conjunto de obras literárias de um país específico, além de remontar procedimentos científicos da História no 
século XIX, surge à esteira do ideal nacionalista romântico.

Além do viés nacionalista, que trouxe a necessidade de resgatar os primórdios do sistema literário de uma determinada nação, as Histórias da Literatura Nacionais oitocentistas tentaram estabelecer - por meio de textos escritos, sejam eles ficcionais, poéticos ou dramáticos; de elementos conceituais, procedimentos metodológicos da História; contribuições da Psicologia, da Sociologia e da Crítica Literária do século XIX - as suas particularidades, a essência que as fizesse ser reconhecidas, no mundo, como pertencentes aos seus países específicos (SOUZA, 2014). Ademais, a ideia de causalidade, que norteava não só a ciência histórica, mas todas as investigações de ordem positivista, direcionou as primeiras tentativas de construir textos de historiografia literária no Ocidente. Nesse sentido, entendia-se que a elaboração de uma obra era determinada pela subjetividade do autor, o meio físico-geográfico em que ele vivia e a sociedade na qual estava inserido.

O historicismo, presente em Histórias da Literatura Nacionais e herdeiro da História oitocentista, está intrinsecamente conectado à noção de causalidade. A partir dele, observa-se uma obra enquanto fruto predeterminado de um contexto histórico. Tal abordagem perdurou ao longo do século XIX e alcançou as primeiras décadas do século XX. Contudo, a partir dos anos 60 e 70, observam-se "[...] transformações significativas com relação às concepções de História" e o ideal de escrita histórica instituído até então, que preza por uma "[...] life-like representation [...]”, perde a sua centralidade absoluta (GUIMARÃES, 2010, p. 46). Isso permite que os historiadores repensem a sua prática profissional - que, de acordo com Manoel Luiz Salgado Guimarães (2010, p. 46), parecia “[...] estar sendo ameaçada pelas críticas advindas de outras disciplinas do campo social [...]" - e empreendam um exercício de reflexão sobre a sua própria disciplina, fato que possibilita que a análise histórica, com a gênese da história das mentalidades, abarque temas até então menosprezados e que foram, antes, tradicionalmente tratados pela Antropologia.

Mais tarde, nos anos 80 do século XX, com o advento da micro-história, tenta-se ultrapassar a oposição clássica e, muitas vezes, vista como não conciliatória entre "[...] subjetividades singulares e determinações coletivas [...]” (GUIMARÃES, 2010, p. 47). Assim, reconhece-se que todo indivíduo está inserido dentro de um contexto histórico, mas que não possui sua vida e ações necessariamente predeterminadas por isso. É por essa razão que:

Como parte de um mesmo movimento, os problemas em torno da representação implicam necessariamente o reconhecimento de um sujeito, ator principal da construção de figuras com as quais significa o mundo, aí compreendendo o próprio passado como parte desta significação do mundo presente. (GUIMARÃES, 2010, p. 47)

Sendo assim, cabe ao historiador, ao empreender um exercício de representação de um passado, principalmente quando esse for acessível apenas por vestígios, questionar a sua própria representação e, mais do que isso, por em xeque suas fontes e pontos de vistas analíticos deterministas, sejam dele mesmo ou de outras representações sobre as quais se debruça. Aliás, no século XIX, o modelo de historia magistra vitae, segundo François Hartog (2017, p. 12), trouxe para a disciplina uma "[...] função tradicional de espelho ou tribunal [...]. Desse modo, a 
História seria a testemunha absoluta do tempo, a Verdade, o lugar por excelência da memória e aquela que teria o papel de unir passado ao presente, levando-os até a posteridade, o futuro.

Contudo, Hartog (2017) aponta para a necessidade de se questionar a escrita historiográfica, pois, antes de tudo, ela pertence ao presente de quem a constrói e não escapa, por mais que se diga o contrário, da subjetividade do historiador. Outrossim, o próprio passado não pode ser plenamente apreensível, pois ele chega até nós a partir de vestígios que são modalizados em dois níveis ou mais: no primeiro, pelo olhar daqueles que primeiro os representou (nesse âmbito estariam fontes primárias); e, no segundo, por quem realiza as suas representações com base em outras (aqui se encontram as fontes secundárias). Quanto mais camadas de representações anteriores o passado que se quer representar possuir, menos acessível será ao historiador, pois a narrativa historiográfica encerra em si recortes, seleções e combinações de informações previamente postas a fim de se construir um discurso específico? Além disso, para constituir-se, ela toma como ponto de partida outros textos de caráter semelhante e que também são norteados pelo viés ideológico de seus escritores.

Cada vez mais, com o exercício reflexivo da História sobre ela mesma, o historicismo, que privilegia o contexto enquanto determinante de um evento, cede espaço para a concepção de historicidade, que pretende compreender o acontecimento, o fato histórico, dentro de toda a complexidade que o envolve, pois, embora ele esteja conectado ao seu tempo e ao espaço em que ocorre, não se restringe meramente a isso. A História é feita por indivíduos e possui como objetos representações de ações de indivíduos e esses, em seu modo de pensar e agir, podem transcender as expectativas postas por quem os representa. Todavia, essa nova consciência sobre a escrita historiográfica entra em conflito com a própria natureza da disciplina que, para constituir-se como tal, precisa sistematizar seus objetos de análise e incluí-los dentro de categorias. Tudo isso trouxe, conforme bem aponta Hartog (2017), uma crise para a Historiografia.

Nas Histórias da Literatura Portuguesa, de modo geral, observa-se que o historicismo ainda possui centralidade. Ainda há nelas uma forte preocupação de apresentar, antes, um contexto para, somente depois, inserir as obras apresentadas, como se essas fossem frutos de uma simples relação de causalidade. No momento em que autores ou livros parecem não se encaixar perfeitamente nos caixilhos criados por toda uma tradição de historiografia da literatura lusa, eles, não raramente, são remetidos como estranhos, menores e deslocados do "seu tempo".

Afora o que se discutiu até aqui, cabe também realizar as distinções entre as expressões História da Literatura e Historiografia Literária realizadas por Roberto Acízelo de Souza (2014). A primeira, em conformidade com o crítico, designa "o fenômeno constituído pelos desdobramentos e transformações no tempo de uma entidade chamada literatura", ao passo que a segunda nomeia "o corpo de obras consagradas ao estudo desse fenômeno" (SOUZA, 2014, p. 15 - grifos do autor).

\footnotetext{
${ }^{7}$ Nota-se que, como pontua Wolfgang Iser (2013), em O fictício e o imaginário: perspectivas para uma Antropologia literária, o texto ficcional, tendo por parâmetro um determinado contexto, parte, antes de tudo, dos atos de fingir da seleção e da combinação a fim de realizar a representação de realidades possíveis. Esses dois atos de fingir preliminares são compartilhados pela escrita historiográfica e literária. A esta última caberia de modo exclusivo apenas um ato de fingir: o desnudamento de sua ficcionalidade.
} 
Contudo, faço aqui um adendo às definições do teórico, pois não se trata do fenômeno literário em si, mas sim da forma que ele é percebido e narrado pelo historiador da literatura. Nesse sentido, compreende-se aqui que a primeira expressão encerra uma representação - modalizada pelo olhar, recorte, seleção, combinação e organização de ideias de quem escreve e a serviço da constituição de um cânone - do processo de construção, de desdobramentos e de mudanças de um sistema literário.

\section{$3 \mathrm{O}$ cânone literário e a literatura portuguesa do século XVI}

O cânone - ou cânon - é uma palavra derivada do termo grego kavóvas, que originalmente denominava uma espécie de vara utilizada como um instrumento de medição. Ao ser retomado por outros campos do conhecimento, esse vocábulo ressignificou-se e passou a designar um conjunto de regras e/ou modelos de organização de determinados assuntos ou objetos. No caso da literatura, os textos canônicos, em tese, configurar-se-iam como um conjunto de obras consideradas, ao longo do tempo, genuínas e oficialmente sancionadas. Para Harold Bloom (1995, pp. 27-28):

O cânone, palavra religiosa em suas origens, tornou-se uma escolha entre textos que lutam uns com os outros pela sobrevivência, quer se interprete a escolha como sendo feita por grupos sociais dominantes, instituições de educação, tradições de crítica, ou, como eu faço, por autores que vieram depois e se sentem escolhidos por determinadas figuras ancestrais. Alguns partidários do que se encara como radicalismo acadêmico chegam mesmo a sugerir que as obras entram no Cânone devido a bem-sucedidas campanhas de publicidade e propaganda.

Outrossim, o crítico literário estadunidense salienta que "as defesas ideológicas do Cânone são tão perniciosas em relação aos valores estéticos quanto as agressões dos atacantes que buscam destruí-lo ou 'abri-lo'” (BLOOM, 1995, pp. 29-30). Contudo, apesar de não se colocar contra ou a favor de nenhum desses três grupos, o autor contradiz-se, pois, em seu livro ele tenta estabelecer/delimitar o que faz parte do que entende enquanto um "Cânone Ocidental". Desse modo, para fazer parte desse seleto grupo, os escritores devem ser "[...] subversivos de todos os valores, tanto nossos quanto deles próprios” (BLOOM, 1995, p. 36), tratarem de problemáticas atemporais, além de aumentarem, a partir da recepção de seus escritos "[...] o nosso próprio eu crescente" (BLOOM, 1995, p. 36). Contudo, esse último aspecto não estaria ligado ao ato de tornar alguém melhor ou pior, mas de aproximar o ser humano do confronto com questões presentes em sua própria existência e com a sua finitude.

No entanto, por mais que não deixe de seguir um critério normativo, que parte do que a teoria e crítica literárias convencionaram como algo "bom" em diversos sistemas literários, e reafirme a necessidade da existência do Cânone na qualidade de instituição fechada, Harold Bloom (1995, p. 46) não se vincula exatamente à tradição canônica convencional, pois, conforme ele mesmo salienta, não se encontra a serviço da defesa "do Ocidente ou uma empresa nacionalista”, porque os fatores observados para a sua seleção de obras foram: valor estético, atemporalidade e universalidade. Nesse sentido, também, o adjetivo "ocidental" não 
marcaria uma predileção, mas um recorte.

A partir do século XIX, momento no qual surgiu a preocupação de estabelecer, nos mais diversos territórios, uma literatura nacional e, portanto, particular e singular, a ideia de formação de um cânone específico para cada país ganhou relevo. Assim, as primeiras historiografias literárias oitocentistas, além de territorialmente marcadas, eram militantes do nacionalismo proveniente do Romantismo. No Brasil, conforme Alfredo Bosi (2002, p. 13), "o ímpeto nacional-romântico resistiu e sobreviveu conforme as condições políticas locais, e pôde resistir até o nosso tempo, reavivando-se sempre que o conflito ideológico e de um imaginário o alimente". Em Portugal, não foi diferente. Antes mesmo da escrita das primeiras historiografias literárias lusas, reconhecidos autores românticos, como Alexandre Herculano ${ }^{8}$ e Almeida Garrett, tentaram delimitar a presença de aspectos nacionalistas e de uma identidade portuguesa na literatura do país:

Quem cantava um assunto nacional, quem descrevia um sítio da sua terra, quem recorria a outro maravilhoso que não fosse o do Olimpo? Toda a nossa literatura era francesa como o reflexo grego e latino; ainda quando os assuntos eram nacionais, não passava de nacionalidade dos nomes dos heróis ou dos títulos dos poemas. O Garção, o Tolentino, o Francisco Manuel vê-se que sentiam a falsidade do tom em que estavam afinadas as suas belas e riquíssimas liras, mas acadêmicos ainda muito poderosos então. Bocage teria podido fazê-lo; mas aquele pasmoso talento nunca reflectiu no que era e podia, nem na alta missão a que o chamavam, tanto o seu génio como a sua popularidade.

Não me atrevo a dizer que já temos uma literatura nacional, nem siquer [sic] sei se chegaremos a isso; mas é sem dúvida que para lá caminhamos, e com mais largos e mais certos passos do que nunca, desde Os lusíadas para cá. (GARRETT, 2007, p. 161)

Luís Vaz de Camões, elogiado pelo romancista anteriormente citado por ter dado o pontapé inicial ao que o autor oitocentista chama de "literatura nacional", como se sabe, esteve, de certo modo, esquecido entre os seus compatriotas até ser resgatado pelos românticos em Portugal, principalmente pelo próprio Garrett, que inaugura o Romantismo em seu país, em 1825, com Camões, poema biográfico que logrou unir a imagem e o destino do poeta renascentista ao de sua nação. Por conseguinte, a lírica e a épica camoniana passaram a ocupar um espaço central não somente no cenário do século XVI, mas também no âmbito do cânone literário português, de modo geral. Para o ensaísta Eduardo Lourenço (1999, p. 57):

A identificação de Portugal com Camões, por obra conjugada dos

\footnotetext{
${ }^{8}$ A crítica literária desse historiador e romancista pode ser encontrada em: HERCULANO, Alexandre. Opúsculos: Literatura. Tomo IX. Lisboa: Bertrand, 1097. Nessa obra especificamente, o prosador, além de preocupar-se com questões semelhantes às de Garrett quanto ao estatuto de nacionalidade da literatura lusíada entre seus contemporâneos, apresenta um artigo dedicado às novelas de cavalaria portuguesas do século XV. Contudo, apesar do título no plural, ele detém-se, em maior parte, em uma discussão - em voga ainda hoje - na qual tenta provar que o Amadis de Gaula tem origem lusitana e não francesa ou espanhola. As demais obras novelísticas quatrocentistas apresentadas em seu texto são, por sinal, traduções e não escritos originais. Já sobre as novelas de cavalaria lusas do século XVI - período em que de fato houve livros autorais lusos desse subgênero literário -, Herculano informou que trataria em um artigo subsequente que, aliás, se foi de fato escrito, nunca veio a público.
} 
acontecimentos históricos e da revolução cultural romântica, é um caso singular no âmbito da cultura européia. Ao longo do século XIX, há uma espécie de vaivém entre a leitura que fazemos de nosso destino coletivo e a imagem de Camões. Ou, antes, do seu Livro, que se converterá ao mesmo tempo na estátua do comandante da nossa cultura e seu anjo da guarda, em nosso juiz e nossa esperança de redenção.

Do século XVI ao XVIII, não era a epopeia e sim outro gênero épico que ocupava um local de destaque no escopo da literatura portuguesa: a novela de cavalaria ${ }^{9}$. Nesse ínterim, podemos destacar alguns autores lusos que se debruçaram sobre esse subgênero: João de Barros, Jorge Ferreira de Vasconcelos, Francisco de Morais, Diogo Fernandes, Leonor Coutinho ${ }^{10}$, Francisco Moraes de Sardinha, Tristão Gomes de Castro, Álvaro da Silveira, Baltasar Gonçalves, Inácio Rodrigues Védouro, Jerónimo Moreira de Carvalho, José Alberto Rodrigues, e Alexandre Caetano Gomes Flaviense.

Em relação às novelas de cavalaria arturianas lusitanas do século XVI, as historiografias literárias portuguesas pouco ou quase nada tratam. $\mathrm{O}$ espaço concedido a elas é muito reduzido quando comparado ao que se dá a autores do período que estariam ligados às tendências classicistas. Dentre esses e além desses, Camões surge como o principal autor do sistema literário no qual se insere. Já a épica de raiz medieval no Quinhentismo é tratada, não raramente, como algo estranho à "nova mentalidade" inaugurada a partir do Renascimento. Dessa forma, por não estarem em conformidade com a estética do Classicismo e também, salvo a Crônica do Imperador Clarimundo, por não apresentarem maiores referências à ideia de construção e consolidação, por meio da literatura, de uma nacionalidade lusa, as narrativas cavaleirescas perderam, gradualmente, a sua centralidade e destaque.

Como aponta Zahidé Lupiaacci Muzart (1995), a construção do cânone em qualquer sistema literário perpassa problemáticas muito parecidas e está diretamente ligada às ideologias dominantes de cada época. Por essa razão, uma obra que merece destaque em uma determinada geração, por atender aos critérios vigentes do seu tempo que a incluem no escopo do cânon, pode, posteriormente, ao deparar-se com novos fatores ideológicos dominantes, não mais ser reconhecida como notória:

O estudo do cânone está ligado, pois, a várias coisas, principalmente à dominante da época: dominantes ideológicas, estilo de época, gênero dominante, geografia, sexo, raça, classe social e outros. Aquilo que é canonizado em certas épocas, é esquecido noutras; o que foi esquecido numa, é resgatado em outra. Como Sousândrade, no Brasil, como Baudelaire, na França... entre outros. (MUZART, 1995, p. 86)

Ao longo do tempo, normas específicas, que determinam o que é esteticamente bom ou

\footnotetext{
${ }^{9}$ A presença da novela de cavalaria em Portugal e na Espanha foi marcante ao longo de cinco séculos, pois, antes mesmo de haver nesses países publicações autorais, as novelas francesas em seu idioma original e, posteriormente, as suas traduções adentraram esses territórios desde o século XIII.

${ }^{10}$ A Condessa Leonor Coutinho, em um cenário de autoria majoritariamente masculina, principalmente no que diz respeito às novelas de cavalaria, escreveu, na primeira metade do século XVII, a obra "Crônica do Imperador Beliandro, em que se dá conta das obras maravilhosas dos valorosos acontecimentos, que no seu tempo obrou o Príncipe Belifloro seu filho, e de Dom Belindo, principe de Portugal, e outros muitos cavaleiros".
} 
não, moldam-se. Com o passar dos anos, à medida que os interesses, gostos e perspectivas acerca do que é belo modificam-se, o que se reconhece na qualidade de cânone pode sofrer - ou não alterações ${ }^{11}$. Quando se trata de textos literários, comumente classifica-se os que se configuram enquanto ruins ou bons, a ponto de serem afastados ou incluídos dentre o grupo de obras canônicas. Via de regra, a noção do que se considera literatura e a formulação do cânone encontram-se diretamente interligadas. De acordo com Márcia Abreu (2006, p. 39):

Por trás da definição de literatura está um ato de seleção e exclusão, cujo objetivo é separar alguns textos, escritos por alguns autores do conjunto dos textos em circulação. Os critérios de seleção segundo boa parte dos críticos é a literariedade imanente aos textos, ou seja, afirma-se que os elementos que fazem de um texto qualquer uma obra literária são internos a ele e dele inseparáveis, não tendo qualquer relação com questões externas à obra escrita, tais como o prestígio do autor ou da editora que o publicou, por exemplo. Entretanto, na maior parte das vezes, não são critérios linguísticos, textuais ou estéticos que norteiam essa seleção de escritos e autores. [...] Entra em cena a difícil questão do valor, que tem pouco a ver com os textos e muito a ver com posições políticas e sociais.

Ao tratar sobre o cânone, é necessário ter em mente todas as dialéticas que envolvem a sua construção, valoração e legitimação. Destarte, a atribuição de valor estético, como vimos, muito além do texto propriamente dito, interliga-se a concepções políticas e sociais vigentes em cada período da História. Cientes disso, alguns críticos literários, a partir do advento dos Estudos Culturais, trouxeram à esteira das discussões acerca da constituição do grupo de obras canônicas conhecidas em cada sistema literário, propostas que visaram, repensar e desmistificar, a partir do resgate de obras esquecidas, os diversos processos de formulação, ao longo dos séculos, do cânon e, talvez, após isso, acrescentar algo a ele.

\section{A busca da construção de uma identidade nacional e a historiografia literária lusitana}

O primeiro texto publicado que pretendeu formular uma "história da literatura portuguesa” é de 1909 e foi escrito por Teófilo Braga. Este, por sua vez, como não poderia deixar de ser, constrói sua obra sob a égide nacionalista do Romantismo e, portanto, no processo de seleção dos textos que adentram, para o autor, o cânone literário luso, a tríade nação, território e língua apresenta-se como um elemento norteador:

a elaboração da Literatura portuguesa é o produto do ethos da raça, do sentimento da nacionalidade e da consciência histórica, acompanhando solidariamente a evolução estética das Literaturas românicas, na Idade Média, na Renascença e na época do Romantismo, seguindo a acção hegemónica de cada uma delas, e por seu turno influindo também na criação da Novela de Cavalaria e na corrente do Humanismo. O estudo histórico deste produto superior do génio português, acompanhando-o nas suas relações com as Literaturas modernas, através dos movimentos sociais e políticos da península

\footnotetext{
${ }^{11}$ De modo geral, a movência do cânone é um evento lento e gradual e que costuma excluir mais que incluir obras ao grupo reconhecido enquanto "literatura de qualidade".
} 
hispânica, presta-se à aplicação de processos críticos, que só podem realizar-se compreendendo a psicologia colectiva e o ponto de vista sociológico. (BRAGA, 2005, p. 52)

Outrossim, a própria premissa de construção de uma historiografia literária nacional já é em si um projeto atrelado ao Romantismo, como apontamos. Sendo assim, em livros desse gênero, busca-se definir o conjunto de obras pertencentes ao cânone de uma determinada nação com base na proveniência e idioma que possuem autor e obra, respectivamente. Desse modo, Teófilo Braga (2005), na publicação referida anteriormente, considera a literatura um fenômeno não apenas estético, mas também historicista, social e que possui indícios de seu espaço de pertencimento, seja na cor local, na língua ou nos temas abordados. Por essa razão, ao tratar sobre novelas de cavalaria, ele retoma uma querela antiga: a definição e comprovação da nacionalidade portuguesa do Amadis de Gaula.

Entretanto, quando parte para as publicações do mesmo subgênero da obra anteriormente mencionada, Teófilo (2005) atém-se a três: Crônica do Imperador Clarimundo, Palmeirim de Inglaterra e Memorial de Proezas da Segunda Távola Redonda. Contudo, sobre esses livros ele faz brevíssimos e superficiais comentários. Em relação ao primeiro, ele afirma que serviu apenas para formar o autor na qualidade de historiador do seu tempo. No momento em que menciona o segundo, o crítico tenta delimitar os aspectos definidores de sua nacionalidade, ao passo que, ao abordar o terceiro, apenas o Torneio de Xabregas, no qual aparece o único cavaleiro de origem portuguesa da narrativa, merece relevo de sua parte.

$\mathrm{Na}$ História da Literatura Portuguesa ${ }^{12}$, de Joaquim Mendes dos Remédios, só há menção de um novelista quinhentista: João de Barros. Contudo, apenas se menciona, de modo superficial a existência da Crônica do Imperador Clarimundo, afirmando-se apenas que essa novela "[...] se trata de trabalho original de Barros, que nela quis experimentar os recursos de sua imaginação de pouco mais de vinte anos [...]” (REMÉDIOS, 1930, p. 180). Afora isso, outros escritos, historiográficos e filosóficos, foram citados. Todavia, conquanto o Amadis de Gaula não adentre, para ele, o escopo da literatura de seu país, essa narrativa mereceu destaque em sua Introdução, na qual enfatizou categoricamente que, ainda que não possua autoria e nacionalidade certa, o "Amadis é a única novela cavaleiresca que merece ler-se" (REMÉDIOS, 1930, p. 57 - grifo do autor).

Na História Literária de Portugal (séculos XII-XX), de Fidelino Figueiredo, publicada originalmente em 1944, em relação às narrativas cavaleirescas do século XVI, o autor adentra na mesma querela da qual Teófilo Braga também participa acerca da nacionalidade lusa do Amadis de Gaula a ser comprovada. Todavia, apesar não contemplar, em sua análise da novelística quinhentista, a obra Duardos de Bretanha, de Diogo Fernandes, ele é um dos poucos historiadores que dão um lugar de destaque às novelas de cavalaria ao associar a existência delas ao desenvolvimento do romance moderno português.

Ademais, sobre a novelística renascentista, afirma-se que "esta continua uma tradição literária medieva ou cria novas formas nos séculos modernos" (FIGUEIREDO, 1960, p. 141).

\footnotetext{
${ }^{12}$ Esta obra não possui edições recentes. A última feita em grande escala data de 1930. Além disso, é possível reeditá-la sob encomenda, por meio da editora inglesa Forgotten Books.
} 
Ao longo das dez páginas dedicadas à novelística lusitana do século XVI, Figueiredo (1960) debruça-se sobre o valor estético de todas as obras das quais se propõe a tratar. Além disso, ele organiza os seus subcapítulos de tal modo que essa parte surge antes do comentário de dezesseis páginas que reservou para Camões. Isso também se mostra como algo inovador e que denota, de igual modo, o valor que o historiador literário atribui ao épico quinhentista de raízes medievais. Diferente desse, Massaud Moisés (2013) traz Luís Vaz de Camões como o primeiro autor a ser abordado na seção Classicismo de A Literatura Portuguesa, que teve a sua primeira edição em 1986. Aliás, o sumário do livro traz os nomes de João de Barros, Jorge Ferreira de Vasconcelos e Francisco de Moraes separadamente e com a sua respectiva paginação. Contudo, no trecho dedicado ao comentário acerca dos autores e suas respectivas obras não está seccionado, como ocorre em outras seções do texto. $\mathrm{O}$ crítico literário brasileiro dedica um parágrafo de dez linhas para tratar dos três escritores e, nessa parte, atém-se a associar cada um ao se respectivo escrito, trazendo os anos de publicação e uma ligeira tentativa de associar cada novelista aos "[...] novos ares da Renascença [...]" (MOISÉS, 2013, p. 104). Afora isso, ele também, assim como Figueiredo (1960) esquece-se completamente do Duardos de Bretanha.

Já a História da Literatura Portuguesa, de António José Saraiva e Óscar Lopes (1956), publicada pela primeira vez em 1955, dedica sete páginas para comentar as mesmas três obras novelísticas abordadas pelos historiadores literários anteriores. Ademais, os autores já reconhecem o Amadis de Gaula enquanto uma produção não portuguesa, privilegiando somente as novelas de cavalaria quinhentistas de autoria lusitana reconhecida. Contudo, há, no decorrer do comentário feito acerca de Clarimundo, uma tentativa de associá-lo à epopeia camoniana por reconhecer no quarto capítulo da narrativa de João de Barros a presença de versos em oitavas e esquema rímico abbaacca ditados pelo feiticeiro Fanimor, que, segundo eles, seria um esboço de um poema épico precursor de Os Lusiadas. Já no Palmeirim de Inglaterra, não se reconhece valor estético, mas vê-se destaque nele por ter uma "[...] construção sintáctica correta, tanto na narração como no diálogo cortês [...]" (SARAIVA; LOPES, 1956, p. 222). Quanto ao Memorial de Proezas da Segunda Távola Redonda, o único fator que chama a atenção é justamente o torneiro de Xabregas, onde, como sabemos, surge o cavaleiro português Dom Lucidardos.

De modo geral, as quatro Histórias da Literatura Portuguesa averiguadas possuem, inegavelmente, um grande fator em comum: a relação que se tenta estabelecer entre texto e contexto. Por essa razão, partindo de uma perspectiva historicista, elas apresentam sempre no início um tópico inicial em cada capítulo. No caso das partes que se referem ao século XVI, primeiramente, há um momento em que se aborda o Renascimento no Ocidente, que traz, claro, um foco em sua origem italiana. Em seguida, discute-se o seu desdobramento, principalmente após a viagem de Francisco Sá de Miranda à Itália, em Portugal.

Massaud Moisés (2013), ao tratar do período quinhentista na literatura, opta pelo termo Classicismo. Isso ocorre porque, provavelmente, o crítico compreendia o termo Renascimento na qualidade uma nomenclatura atrelada a um momento que atingiu a cultura ocidental em vários campos do conhecimento, ao passo que, entre os portugueses, o que houve foi uma imitação e emulação dos clássicos em um nível estético simplesmente. Por essa razão, ele inicia essa seção específica com a encenação da derradeira peça teatral de Gil Vicente e o posterior advento da tendência literária que seguiu o "Humanismo". 
Para Moisés (2013, p. 66), foi sob o "[...] ímpeto revolucionário da Renascença e, com o desenvolvimento natural do Humanismo, que o Classicismo se difundiu amplamente, por corresponder, no plano literário, ao geral e efêmero complexo de supremacia histórica”. Além disso, ele atrela o "achamento" do Brasil, em 1550, a um "[...] otimismo ufanista [...]" (MOISÉS, 2013, p. 66) que possibilitou a existência de uma obra como Os Lusíadas.

Joaquim Mendes dos Remédios (1930), por sua vez, também atrela eventos históricos à criação de um novo tipo de sensibilidade em Portugal que culminou no Renascimento. Segundo ele, nesse período, "Portugal acompanhava a febre de progresso, que aquecia toda a Europa culta” (REMÉDIOS, 1930, p. 138). Devido a isso, é apontada uma série de avanços em práticas sociais de clérigos, senhores e damas ilustres motivados pela inauguração de uma "[...] era moderna [...]” (REMÉDIOS, 1930, p. 138). Consequentemente, por, em suas concepções, não se desvencilharem disto, os autores renascentistas e suas respectivas obras conectar-se-iam com a modernidade ao renovarem as suas perspectivas estéticas.

Não é de se estranhar, portanto, o pouco destaque que Mendes dos Remédios (1930) oferece para a novela de cavalaria no século XVI, pois elas negam, simplesmente pelo fato de existirem, a relação de causalidade estabelecida no texto. Outrossim, há também, como se sabe, a não abordagem de outras obras e autores que se debruçaram sobre esse gênero. Considerar a existência de narrativas cavaleirescas em pleno quinhentismo desmontaria toda a perspectiva determinista, que situa a obra como resultante de um autor que, inserido em um contexto, produz literatura. Não se enfatiza, portanto, a criação literária enquanto um fenômeno no qual evento, subjetividade do escritor e livro nem sempre convergem. A criação de um poema épico como Os Lusíadas - em uma sociedade que conservou, para além do período medieval, uma estrutura econômica e social muito próxima à feudal - já revela que o poeta enquanto indivíduo não era predeterminado pela conjuntura predominante em seu país. Ao contrário disso, tentouse realizar o jogo inverso, trazendo o Renascimento para o centro de sua criação literária.

Fidelino Figueiredo (1960), embora dê destaque às novelas de cavalaria quinhentistas sem deixar de tratar de obras atreladas a um viés renascentista e, por isso, construa uma História da Literatura Portuguesa mais interessante em relação ao século XVI sob o ponto de vista estético e historiográfico, não deixa de atrelar os textos sobre os quais trata ao contexto histórico. Sobre as narrativas cavaleirescas, ele afirma que são "[...] um problema difícil", justamente por destoarem da tônica de outras publicações canônicas do período, mas que "é certo que foi a Renascença que the deu grande possibilidade de desenvolvimento" (FIGUEIREDO, 1960, p. 141). Dessa maneira, além de se preocupar em realizar uma Introdução Histórica, ele não deixa de reconhecer, de certo modo, um caráter determinante do contexto que ele apresenta nessa seção.

António José Saraiva e Óscar Lopes (1956) apresentam em “3a Época - Renascimento e Maneirismo" uma série de aspectos sociais, históricos e culturais que teriam fomentado a literatura portuguesa quinhentista. É por esse motivo que, para eles, quanto mais se pode encontrar - de modo, muitas vezes, forçado - elementos que aproximem as novelas de cavalaria às categorias gerais do Renascimento ou a Camões, maior valor estético possuem. Quando isso não é possível, o que resta é desqualificá-las enquanto literatura. 


\section{Considerações finais}

De modo geral, como se pode observar nas quatro Histórias da Literatura Portuguesa duas da primeira metade do século XX e as outras da segunda metade -, a novela de cavalaria Duardos de Bretanha, de Diogo Fernandes, não é nem ao menos citada, o que pode revelar, talvez, o desconhecimento da existência da obra por parte dos historiadores da literatura analisados. Afora isso, há outro fator em comum: três Histórias da Literatura Portuguesa - a de Fidelino Figueiredo (1960); a de António José Saraiva e Óscar Lopes (1956); e a de Massaud Moisés (2013) - destacaram as mesmas três prosas cavaleirescas de autoria reconhecidamente lusa: o Clarimundo; o Memorial de Proezas da Segunda Távola Redonda; e o Palmeirim de Inglaterra.

No entanto, dentre as historiografias literárias abordadas, somente a de Fidelino Figueiredo (1960) não reconhece a presença do subgênero novela de cavalaria como um fator de total atraso para o século XVI, pois vê exatamente na novelística renascentista uma porta de entrada para novos subgêneros ou a reformulação dos que já existiam e, possivelmente, para a criação e consolidação de novos gêneros literários. Já as demais obras que se propõem a estabelecer o escopo da literatura portuguesa e atribuir-lhe valor, vêem a permanência da prosa cavaleiresca como um anacronismo frente às tendências renascentistas/classicistas, que deveriam ser valorizadas em detrimento de uma forma de narrativa originada no medievo.

Além disso, Camões e sua epopeia ocupam nos capítulos dedicados ao Renascimento em Portugal uma centralidade absoluta na maioria das vezes, o que faz com que os escritos épicos de João de Barros, Jorge Ferreira de Vasconcelos, Francisco de Moraes sejam postos à margem. O poeta-navegante legou à tradição um vasto poema que pode servir aos interesses nacionalizantes que o Romantismo outorgou para as Historiografias da Literatura Portuguesa e que também se fez útil para a política e formulação de uma autoimagem lusitana respaldada em um dito passado glorioso que, no presente, fez-se saudade perpétua.

Sendo assim, atendendo às necessidades nacionalistas de uma História da Literatura Nacional, não raramente os historiadores literários comparam, ou tentam interligar as novelas de cavalaria quinhentistas analisadas por eles ao épico de Camões, que fora feito personificação de um povo, a fim de validá-las em parte. Quando isso não é possível, tenta-se ao menos extrair delas algum elemento de valor pátrio. Por fim, no momento em que se esgotam essas duas possibilidades, menospreza-se o valor estético e a importância histórica e/ou social que esses livros possuem por não se enquadrarem nos aspectos desejados por quem escreve a análise.

Nas Histórias da Literatura Portuguesa, apesar dos avanços na forma de se fazer e pensar a História, prevalece uma perspectiva analítica historicista que corrobora para a difusão de uma versão da história lusa na qual o período medieval teria sido completamente superado pela "era moderna”. Ademais, as obras publicadas, necessariamente, deveriam ser, para os historiadores literários, resultados dessa conjuntura. Por essa razão, urge pensar a literatura lusa a partir da sua historicidade, considerando muito além do que texto e contexto, refletindo sobre essas produções artísticas a partir de sua singularidade e não como se faz ainda hoje, ao se tentar ajustá-las a caixilhos predeterminados. 


\section{Referências}

ABREU, M. Cultura Letrada: Literatura e leitura. São Paulo: UNESP, 2006.

BLOOM, H. O Cânone Ocidental: os livros e a escola do tempo. Tradução de Marcos Santarrita. Rio de Janeiro: Editora Objetiva LTDA, 1995.

BOSI, A. Literatura e Resistência. São Paulo: Companhia das Letras, 2002.

BRAGA, T. História da Literatura Portuguesa: A Idade Média. Lisboa: Europa-América, 1990.

BRAGA, T. História da Literatura Portuguesa: Renascença. Lisboa: Europa-América, 1990.

CASTRO, I. Apresentação. In: MEGALE, H. A Demanda do Santo Graal: das origens ao códice português. São Paulo: Ateliê Editorial, 2001.

FIGUEIREDO, F. História Literária de Portugal séculos XII -XX. Rio de Janeiro: Fundo de Cultura, 1960.

GARRETT, A. Ao Conservatório Real. In: NEVES, L. B. P.; DAVID, S. N.; FERREIRA, T. M. T. B. C.; OLIVEIRA, P. M. Literatura, história e politica em Portugal (1820-1856). Rio de Janeiro: EdUERJ, 2007.

GAYANGOS, P. Libros de cabbalerias, con un discurso preliminar razonado. Madrid: M. Rivadeneyra, 1857.

GUIMARÃES, M. L. S. Expondo a História: imagens do passado construindo o passado. In: GUIMARÃES, M. L. S.; RAMOS, F. R. L. (org.). Futuro do Pretérito: Escrita da História e História do Museu. Fortaleza: Instituto Frei Tito Alencar/ Expressão Gráfica Editora, 2010.

HARTOG, F. Crer em História. Tradução de Camila Dias. 1a ed. Belo Horizonte: Autêntica Editora, 2017.

ISER, W. Atos de fingir. In: ISER, W. O fictício e o imaginário: perspectivas de uma Antropologia literária. Tradução de Johannes Kretschmer. 2a ed. Rio de Janeiro: EdUERJ, 2013.

KOSELLECK, R. Compreensão do Conceito na Idade Média. In: KOSELLECK, R.; MEIER, C.; GÜNTHER, H.; ENGELS, O. O Conceito de História. Tradução de René E. Gertz. 1a ed. 1a reimp. Belo Horizonte: Editora Autêntica, 2016. (Coleção História e Historiografia, 10).

LOURENÇO, E. Mitologia da Saudade: seguido de Portugal como Destino. São Paulo: Companhia das Letras, 1999.

MOISÉS, M. A Literatura Portuguesa. São Paulo: Cultrix, 2003.

MOISÉS, M. A Novela de Cavalaria no Quinhentismo Português: O Memorial de Proezas da Segunda Távola Redonda de Jorge Ferreira de Vasconcelos. São Paulo: Universidade de São Paulo, 1957.

MEIER, C. Antiguidade. In: KOSELLECK, R.; MEIER, C.; GÜNTHER, H.; ENGELS, O. O Conceito de História. Tradução de René E. Gertz. 1a ed. 1ª reimp. Belo Horizonte: Editora Autêntica, 2016. (Coleção História e Historiografia, 10).

MORETTI, F. Signos e estilos da modernidade: ensaios sobre a sociologia das formas literárias. Tradução de Maria Beatriz de Medina. Rio de Janeiro: Civilização Brasileira, 2007.

MUZART, Z. L. A questão do cânone. Anuário de Literatura, Florianópolis, Vol. 1, № 3, pp. 85 94, 1995. 
REMÉDIOS, J. M. História da Literatura Portuguesa: desde as origens até a atualidade. Coimbra: Atlântida, 1930.

SARAIVA, A. J.; LOPES, Ó. História da Literatura Portuguesa. Porto: Porto Editora, 1975.

SOUZA, R. A. História da Literatura: trajetória, fundamentos, problemas. Coordenação: João Cezar de Castro Rocha. 1a ed. São Paulo: É Realizações, 2014.

Recebido em: 23/08/2019

Aceito em: 04/10/2019 